\title{
Comparative proteomics of oxidative stress response of Lactobacillus acidophilus NCFM reveals effects on DNA repair and cysteine de novo synthesis
}

Calderini, Elia; Celebioglu, Hasan Ufuk; Villarroel, Julia; Jacobsen, Susanne; Svensson, Birte; Pessione, Enrica

Published in:
Proteomics

Link to article, DOI:

10.1002/pmic. 201600178

Publication date:

2017

Document Version

Peer reviewed version

Link back to DTU Orbit

Citation (APA):

Calderini, E., Celebioglu, H. U., Villarroel, J., Jacobsen, S., Svensson, B., \& Pessione, E. (2017). Comparative proteomics of oxidative stress response of Lactobacillus acidophilus NCFM reveals effects on DNA repair and cysteine de novo synthesis. Proteomics, 17(5), [1600178]. https://doi.org/10.1002/pmic.201600178

\section{General rights}

Copyright and moral rights for the publications made accessible in the public portal are retained by the authors and/or other copyright owners and it is a condition of accessing publications that users recognise and abide by the legal requirements associated with these rights.

- Users may download and print one copy of any publication from the public portal for the purpose of private study or research.

- You may not further distribute the material or use it for any profit-making activity or commercial gain

- You may freely distribute the URL identifying the publication in the public portal 


\section{Comparative proteomics of oxidative stress response of Lactobacillus acidophilus NCFM reveals effects on DNA repair and cysteine de novo synthesis}

Elia Calderini ${ }^{1,2, \dagger}$, Hasan Ufuk Celebioglu ${ }^{2, \dagger}$, Julia Villarroel ${ }^{2}$, Susanne Jacobsen ${ }^{2,}$, Birte Svensson $^{2 *}$ and Enrica Pessione ${ }^{1 *}$

${ }^{1}$ Università di Torino, Department of Life Sciences and Systems Biology, Via Accademia Albertina 13, 10123 Torino, Italy

${ }^{2}$ Enzyme and Protein Chemistry, Department of Biotechnology and Biomedicine, Technical University of Denmark, Elektrovej, Building 375, DK-2800 Kgs. Lyngby, Denmark

$\dagger$ These authors contributed equally.

${ }^{\S}$ We dedicate this work to the late Susanne Jacobsen

Running title: Lactobacillus acidophilus NCFM response to oxidative stress

*Correspondance: Professor Enrica Pessione, Department of Life Sciences and Systems Biology, Università di Torino, Via Accademia Albertina 13, 10123, Torino, Italy. Tel.: +39 0116704644 ; fax: +39 011 6704508. E-mail: enrica.pessione@unito.it

Professor Birte Svensson, Department of Biotechnology and Biomedicine, Technical University of Denmark, Elektrovej, Building 375, DK-2800 Kgs. Lyngby, Denmark. Tel.:+45 4525 2740; fax: +45 4583 6607; E-mail: bis@,bio.dtu.dk. 


\author{
Abbreviations used: \\ ABM; Antibiotic biosynthesis monooxygenase \\ cfu; Colony forming units \\ GAPDH; Glyceraldehyde-3-p dehydrogenase \\ GIT; Gastrointestinal tract \\ LAB; Lactic acid bacteria \\ LABSEM; Semi-synthetic media for lactic acid bacteria \\ PK; Pyruvate kinase \\ R5P; ribose-5-phosphate \\ PRPP; 5-phospho- $\alpha$-d-ribosyl-1-pyrophosphate \\ PRPPS; Ribose-p pyrophosphokinase \\ ROS; Reactive oxygen species
}

\title{
Keywords:
}

2DE-MS / ClpP-ATP-dependent protease-peptidase / Cysteine synthase / Glyceraldehyde-3 P dehydrogenase / Hydrogen peroxide

Word count: 6242 


\begin{abstract}
Probiotic cultures encounter oxidative conditions during manufacturing, yet protein abundance changes induced by such stress have not been characterized for some of the most common probiotics and starters. This comparative proteomics investigation focuses on the response by Lactobacillus acidophilus NCFM to $\mathrm{H}_{2} \mathrm{O}_{2}$, simulating an oxidative environment. Bacterial growth was monitored by BioScreen and batch cultures were harvested at exponential phase for protein profiling of stress responses by 2D gel-based comparative proteomics. Proteins identified in 19 of 21 spots changing in abundance due to $\mathrm{H}_{2} \mathrm{O}_{2}$ were typically related to carbohydrate and energy metabolism, cysteine biosynthesis, and stress. In particular, increased cysteine synthase activity may accumulate a cysteine pool relevant for protein stability, enzyme catalysis and the disulfide-reducing pathway. The stress response further included elevated abundance of biomolecules reducing damage such as enzymes from DNA repair pathways and metabolic enzymes with active site cysteine residues. By contrast, a protein-refolding chaperone showed reduced abundance, possibly reflecting severe oxidative protein destruction that was not overcome by refolding. The proteome analysis provides novel insight into resistance mechanisms in lactic acid bacteria against reactive oxygen species and constitutes a valuable starting point for improving industrial processes, food design or strain engineering preserving microorganism viability.
\end{abstract}




\section{Statement of significance}

Lactic Acid Bacteria (LAB) are widely used as starter cultures in food fermentation and as probiotics and it is important to secure a high titer of viable cells. During manufacturing processes, however, bacteria go through various stresses, one notably being exposure to oxygen and reactive oxygen species (ROS). Lactobacillus acidophilus contributes beneficial effects on human health, which warranted its wide application as probiotic. In the gastrointestinal tract, probiotics encounter oxidative stress from oxygen gradients and the immune system, possibly reducing viable cell counts below the recommended daily intake. Here, analyses of proteome changes induced by hydrogen peroxide shed light on the molecular response to oxidative stressors and represent a first step towards strain amelioration. 


\section{Introduction}

Lactic acid bacteria (LAB) constitute a heterogeneous group of prokaryotes colonizing different habitats: human and animal bodies, plants, and food [1]. Since LAB are unable to synthesize heme, they lack catalases as well as other oxygen defense enzymes and possess low oxygen tolerance thus being defined as aerotolerant anaerobes [2]. This implicates sensitivity to reactive oxygen species (ROS); superoxide anion radical $\left(\mathrm{O}_{2}^{-}\right)$; hydroxyl radical $\left(\mathrm{OH}^{*}\right)$; and hydrogen peroxide $\left(\mathrm{H}_{2} \mathrm{O}_{2}\right)$. Oxidative stress reflects imbalance between generation of and ability to detoxify ROS or repair resulting damages. Some, but not all, LAB use manganese superoxide dismutase, pseudocatalase and peroxidase or manganese (an $\mathrm{O}_{2}^{-}$scavenger) to convert ROS to harmless compounds $[3,4]$. However, this is not the sole strategy, indeed some LAB devote a large part of their genome to counteracting oxygen stress [5]. Protection mechanisms worth noting include i) increased activity of oxygen consuming routes [6], ii) maintenance of a reducing intracellular environment through disulfide-reducing pathways [7, 8], iii) protection of sensitive thiols by metal ions [9], and as a last resort iv) DNA repair to overcome oxidative damage of the genome [10].

LAB are crucial in food fermentations and contribute to taste and texture of food products [11]. They inhibit food spoilage and pathogenic bacteria by lowering $\mathrm{pH}$ through lactic acid formation and by producing bacteriocins [12]. Thanks to these properties, LAB are used as starters and as biocontrol agents [13]. Furthermore, several LAB are marketed as probiotics, with a range of health benefits $[14,15,16,17,18]$.

Lactobacillus acidophilus is among the most widely used LAB species in yogurt and fermented milk products [19]. The probiotic functionality of L. acidophilus is well documented in vitro and in vivo including attenuation of lactose intolerance, reduction of cholesterol level, 
immunomodulation via stimulation of host cytokines and immunoglobulin A (IgA) expression, exclusion of pathogens, and alleviation of cold-like symptoms in children [20, 21]. L. acidophilus grows optimally at $37-42^{\circ} \mathrm{C}$ [21] suitable for application in food industry, but belongs to the least oxygen tolerant LAB because it lacks superoxide dismutase and has low levels of manganese that constitutes the major antioxidant defense in heme-deficient strains [11]. These features strongly reduce the performance of $L$. acidophilus during harsh industrial processing.

Food starters and probiotics have to cope with oxidative stress at manufacturing stages from fermentation to freeze- and spray-drying used in production of high-density probiotic powder as end-product for the market, and during storage [22]. Several studies recommended a daily probiotics intake of $10^{8}-10^{9}$ colony-forming units (cfu) and food with health claims on probiotics requires at least $10^{6}-10^{7}$ cfu of probiotic bacteria per gram (FAO/WHO, 2001). However, ambient storage temperature and exposure to oxygen might diminish the viable cell count below the recommended limit [23]. Thus, various commercial products contained as little as $\sim 10^{3} \mathrm{cfu} / \mathrm{mL}$ at the end of shelf life, while starting with $10^{7} \mathrm{cfu} / \mathrm{mL}$ [24]. Additionally, survival of probiotics during gastrointestinal tract (GIT) transit depends on ability to sense and respond to steep oxygen gradients [22]. Altogether preserving a high number of viable cells is an important challenge for industrial products.

L. acidophilus NCFM is commercially available since 1972 in the United States in dairy products and dietary supplements. It does not encode a superoxide dismutase, but possesses genes associated with oxygen consuming routes, disulfide-reducing pathways (a thioredoxin system and glutathione reductase) and DNA repair [25]. Reports on levels of relevant enzyme and protein forms are lacking, however, the present comparative proteome analysis discloses important molecular aspects of the response of L. acidophilus NCFM to oxidative stress, a paradigmatic 
condition for microaerophilic LAB physiology. The ultimate goal is to gain insights facilitating control, improvement and optimization of bacterial behavior in industrial starter and probiotics production.

\section{Materials and methods}

\subsection{Bacterial strain and growth conditions}

Growth of L. acidophilus NCFM (NCFM 150B, FloraFIT® Probiotics; DuPont, USA Inc., Madison, WI) without agitation at $37^{\circ} \mathrm{C}$ in $50 \mathrm{~mL}$ cultures in preheated LABSEM supplemented with $1 \%$ glucose [26] was monitored by $\mathrm{OD}_{600}$ (Ultrospec 2100pro, Amersham Biosciences) and pH (Panpeha pH-indicator strips range 0 - 14, Sigma-Aldrich) measurements every 3 h.

\subsection{BioScreen}

The BioScreen instrument (Labsystems BioScreen C, Bie \& Berntsen A/S) allows simultaneous incubation, shaking and OD measurement of up to 200 samples. Cultures at early exponential phase $\left(\mathrm{OD}_{600} \sim 0.2\right)$ were inoculated in fresh preheated LABSEM containing $0.0-1.2 \mathrm{mM} \mathrm{H}_{2} \mathrm{O}_{2}$ [27] and pipetted $(300 \mu \mathrm{L})$ into wells. $\mathrm{OD}_{600}$ was monitored every $30 \mathrm{~min}$ at $37^{\circ} \mathrm{C}$ for $48 \mathrm{~h}$. Three biological replicates each in three technical replicates were analyzed at each condition.

\subsection{Oxidative stress}

Batch cultures $(50 \mathrm{~mL})$ in LABSEM without $\mathrm{H}_{2} \mathrm{O}_{2}$ were harvested $(3200 \mathrm{xg}$, room temperature, 10 min; Centrifuge CR3i, Jouan) at early exponential phase ( $\mathrm{OD}_{600} \sim 0.2 ; \mathrm{t} \sim 12 \mathrm{~h}$ ) and sub-cultured in fresh preheated LABSEM $(50 \mathrm{~mL})$ added nonecontaining no, $0.4,0.8$ or $1.2 \mathrm{mM} \mathrm{H}_{2} \mathrm{O}_{2}$ according to [28]. The experiment was performed in four biological replicates. 


\subsection{Protein sample preparation}

Cells were harvested as above at late exponential phase $\left(\mathrm{OD}_{600} \sim 0.7, \mathrm{t} \sim 35 \mathrm{~h}\right)$, washed with $0.9 \%$ $\mathrm{NaCl}$, disrupted by manual grinding with a small amount of acid-washed glass beads $(<100 \mu \mathrm{m}$ diameter, Sigma-Aldrich) using a rounded glass Pasteur pipette, $60 \mu \mathrm{L}$ of sample buffer $(28 \mathrm{mM}$ Tris- $\mathrm{HCl}, 22 \mathrm{mM}$ Tris-base $\mathrm{pH} 8.5,100 \mathrm{mM}$ DTT) was added to the sample and heated $\left(100{ }^{0} \mathrm{C}\right.$, $2 \mathrm{~min}$ ). added $60 \mu \mathrm{L}$ sample buffer (28 mM Tris-HCl, $22 \mathrm{mM}$ Tris-base pH 8.5, $100 \mathrm{mM}$ DTT) and heated $\left(100^{0} \mathrm{C}, 2 \mathrm{~min}\right)$. After $5 \mathrm{~min}$ at room temperature, $240 \mu \mathrm{L}$ rehydration buffer $(7 \mathrm{M}$ urea, $2 \mathrm{M}$ thiourea, 2\% CHAPS, $20 \mathrm{mM}$ DTT) was added. The mixture was vortexed, centrifuged (10000 x g, $10 \mathrm{~min})$ and the supernatant collected [29]. Protein concentration was determined using the Bradford Protein Assay Kit (Thermo Scientific) and BSA as standard. Proteins were precipitated by addition of four volumes of ice-cold acetone to $\sim 100 \mu \mathrm{g}$ protein $\mathrm{A}$ volume containing $\sim 100 \mu \mathrm{g}$ protein was added four volumes of ice-cold acetone, kept (overnight, $-20^{\circ} \mathrm{C}$ ) [30] and centrifuged $\left(14000 \mathrm{xg}, 25 \mathrm{~min}, 4^{\circ} \mathrm{C}\right)$. Protein pellets were air-dried and dissolved in 350 $\mu \mathrm{L}$ rehydration buffer (8 M urea, 2\% CHAPS, 0.5\% IPG-buffer $\mathrm{pH} 3-10,0.3 \%$ DTT, Orange G) immediately prior to $2 \mathrm{DE}$.

\subsection{DE}

Rehydrated samples (100 $\mu \mathrm{g}$ protein in $350 \mu \mathrm{L}$ rehydration buffer) were loaded on $18 \mathrm{~cm}$ drystrips (pH 3 - 10; GE Healthcare) for IEF (IPGphor; GE Healthcare) at $20^{\circ} \mathrm{C}, 50 \mu \mathrm{A} / \mathrm{strip}$ until $\sim 67 \mathrm{kVh}$ [29]. Strips were then soaked with 2 x $5 \mathrm{~mL}$ equilibration buffer (6 M urea, 30\% glycerol, $50 \mathrm{mM}$ Tris- $\mathrm{HCl} \mathrm{pH} 8.8,2 \% \mathrm{w} / \mathrm{v}$ SDS, $0.01 \%$ bromophenol blue) containing $1 \%$ DTT and 2.5\% iodoacetamide, respectively (15 min each). The second dimension $(12.5 \%$ SDS-PAGE, $26 \times 20 \mathrm{~cm}$ gel size; Ettan ${ }^{\mathrm{TM}}$ DALTsix Electrophoresis unit; GE Life Sciences) was run overnight at $1 \mathrm{~W} / \mathrm{gel}$. 
Gels were stained overnight by CBB G250 [31], destained, and scanned (Scan maker 9800XL, TM1600, Microtek9).

\subsection{Image analysis}

Differentially abundant proteins were revealed using SameSpots software (TotalLab). Interference due to different CBB G250 batches and external conditions affecting spot volume calculation was minimized by comparing gels run together. Fold-changes (SameSpots) were averaged for individual spots and standard deviations calculated of four biological and three technical replicates of stressed and control samples. Data reliability was checked using Student's t-test (Microsoft Excel). Due to low abundance of some proteins displaying changes, high p-values in the range $0.05-0.09$ were also considered, while even higher p-values were just informed. Spots changing at least 1.3-fold between control and $1.2 \mathrm{mM} \mathrm{H}_{2} \mathrm{O}_{2}$ were analysed by MS.

\subsection{In-gel digestion and protein identification by mass spectrometry}

Differentially abundant spots were excised from a master gel and stored (Eppendorf ${ }^{\mathrm{TM}}$ tubes, -20 $\left.{ }^{\circ} \mathrm{C}\right)$ until use. Gel pieces were washed with $40 \%$ ethanol $(100 \mu \mathrm{L})$ at $50{ }^{\circ} \mathrm{C}$ with shaking until colorless and the ethanol was decanted. $\mathrm{ACN}(30 \mu \mathrm{L})$ was added to shrink the gel (10 min) and removed. Gel pieces were air-dried leaving lids open in a LAF bench (10 min), added $5 \mu \mathrm{L} 12.5$ ng/ $\mu \mathrm{L}$ trypsin (Promega) in $25 \mathrm{mM} \mathrm{NH}_{4} \mathrm{HCO}_{3}$, kept on ice (45 min), added $10 \mu \mathrm{L} \mathrm{NH}_{4} \mathrm{HCO}_{3}$ and incubated (overnight, $37^{\circ} \mathrm{C}$ ). Supernatants were transferred to fresh tubes and stored at $-20{ }^{\circ} \mathrm{C}$ until MS. Digests $(1 \mu \mathrm{L})$ were loaded on a MALDI AnchorChip target (Bruker-Daltonics), airdried (20 min), added $1 \mu \mathrm{L}$ matrix solution $(0.5 \mu \mathrm{g} / \mu \mathrm{L} \mathrm{CHCA}$ in 90\% ACN, $0.1 \% \mathrm{TFA})$, air-dried and washed with $2 \mu \mathrm{L} 0.5 \%$ TFA. Tryptic peptides of $\beta$-lactoglobulin were used for calibration. MS spectra were obtained (Ultraflex II MALDI-TOF MS mass spectrometer; Bruker-Daltonics) 
in auto-mode using Flex Control v.3.0 (Bruker-Daltonics). Peaks were identified after calibrating the Flex Analysis v3.0 software (Bruker-Daltonics) to exclude peaks of autodigested trypsin and keratin. Spectra were searched in NCBI nr database for bacteria (NCBI nr 20140323; 38032689 sequences; 13525028931 residues) using MASCOT 2.0 (http://www.matrixscience.com) integrated in Biotools v3.2 (Bruker-Daltonics). Search parameters were monoisotopic; peptide mass tolerance $\pm 50 \mathrm{ppm}$; maximum of one missed cleavage; fixed carbamidomethylation of cysteine; partial oxidation of methionine. Identification by PMF was confirmed with a MASCOT score of $86(\mathrm{p} \leq 0.05)$ and a minimum six of matched peptides [29].

\section{Results}

\subsection{BioScreen}

Growth of L. acidophilus NCFM with $0.0-1.2 \mathrm{mM} \mathrm{H}_{2} \mathrm{O}_{2}$ present was analyzed [7, 27] using BioScreen, which indicated a critical level of $0.4 \mathrm{mM} \mathrm{H}_{2} \mathrm{O}_{2}$ causing stress without being lethal. The growth was retarded as reflected by the longer lag phase and deferred start of exponential phase. The slope of the exponential phase decreased with $0.4 \mathrm{mM} \mathrm{H}_{2} \mathrm{O}_{2}$ and growth stopped at $\mathrm{H}_{2} \mathrm{O}_{2}>0.4 \mathrm{mM}$ (Fig. 1).

\subsection{Growth curves and $\mathrm{pH}$ profiles}

The time-course of bacterial growth can provide insight into influence of environmental conditions. In standard medium (LABSEM, pH 5.5 - 6.0) L. acidophilus NCFM enters exponential phase after $\sim 10 \mathrm{~h}$ and stationary phase at $\sim 24 \mathrm{~h}$. $\mathrm{pH}$ of the culture decreases $(\mathrm{pH} 4.0-4.5)$ due to lactic acid production. Initially, the effect of $0.4 \mathrm{mM} \mathrm{H}_{2} \mathrm{O}_{2}$ was tested as this was the highest concentration allowing growth in BioScreen (Fig 1). Following a protocol of Serata et al. [32], 0.4 
$\mathrm{mM} \mathrm{H}_{2} \mathrm{O}_{2}$ was added $7 \mathrm{~h}$ after the inoculum, without L. acidophilus NCFM displaying appreciable stress (data not shown). Previously $0.6-1.2 \mathrm{mM} \mathrm{H}_{2} \mathrm{O}_{2}$ was found to decrease, but not completely arrest L. acidophilus growth [27]. Therefore $0.8 \mathrm{mM}$ or $1.2 \mathrm{mM} \mathrm{H}_{2} \mathrm{O}_{2}$ was added at the start of the exponential phase, using the Bruno-Bàrcena protocol [27]. The growth was slightly more slowed at 1.2 than $0.8 \mathrm{mM} \mathrm{H}_{2} \mathrm{O}_{2}$ (Fig. 2A).

\subsection{Growth curves and pH profiles after sub-culturing}

Cells were transferred to fresh medium supplemented with $\mathrm{H}_{2} \mathrm{O}_{2}\left(\mathrm{OD}_{600} \sim 0.2,12-15 \mathrm{~h}\right.$, see Methods) L. acidophilus NCFM entered an adapting lag phase (Fig. 2B) and synthesized molecules to cope with the stress. The lag phase in $1.2 \mathrm{mM}$ was longer than in $0.8 \mathrm{mM} \mathrm{H}_{2} \mathrm{O}_{2}$ and the corresponding $\mathrm{pH}$ profiles differed importantly (Fig. 2B; Supporting Fig. S1), also considering the pH was measured by using indicator paper.". Notably re-adaptation after sub-culture is well-known to cause a second lag prior to the manifested decrease in $\mathrm{pH}$ [33]. Because more significant changes in protein abundance were assumed for $1.2 \mathrm{mM} \mathrm{H}_{2} \mathrm{O}_{2}$, only this culture was subjected to differential proteome analysis.

\subsection{DE-based comparative proteome analyses}

Stressed and control cultures were harvested in late exponential phase (OD $600 \sim 0.7)$. In total 507 spots were detected by 2DE of the intracellular proteins. Comparison of stressed and control cultures revealed 21 differentially abundant spots (Fig. 3; Table 1) using a threshold of 1.3 fold relative abundance change of spots selected for MS analysis [30]. The resulting PMFs searched against NCBI identified 19 unique proteins from L. acidophilus NCFM with a high MASCOT score, except for ribose-p-pyrophosphokinase (spot 18) that gave a PMF score of 77 (Table 1, Supporting Table S1). The proteins are classified into functional categories i) energy metabolism; 
ii) nucleic acids; iii) general stress; and iv) oxidative stress, discussed below. Protein abundancy changes were supported by semi-quantitative RT-PCR (Supporting Methods S1) analysis of expression of four selected genes (lba0698 encoding GAPDH, lba0957 encoding pyruvate kinase (PK), lba0497 encoding antibiotic biosynthesis monooxygenase, and lba 1248 encoding heat shock protein GrpE), using expression of 16S rDNA (lba2001) as internal control (Supporting Fig. S2) [29].

\section{Discussion}

Stress responses play a key role in cellular adaptation of all organisms to changes in the environment. The best known biological stress reaction is synthesis of chaperones and proteases which counter accumulation of aberrant proteins [34]. As LAB evolved on Earth before oxygen appeared in the atmosphere [5], accommodating oxidative stress has high priority. Bacteria may use non-enzymatic $\left(\mathrm{Mn}^{2+}\right.$, ascorbate, tocopherols, glutathione) and enzymatic (thioredoxin and thioredoxin-reductase, catalase, NADH oxidases, NADH peroxidases, superoxide dismutase) systems for defense against ROS. LAB genomes however, mostly do not encode enzymes eliminating ROS, which adversely affect cell fitness by attacking proteins, lipids and nucleic acids, and represent a major cause of cell death [35].

Reports specifically addressing oxidative stress defense in probiotic prokaryotes are scarce and only concern Bifidobacterium longum [36] and Lactobacillus sakei [37]. A larger number of papers (mainly review articles) refer to concerted physiological responses to general stressors (heat, cold, carbon starvation, osmotic, oxidative and acidic stress) both in $\operatorname{LAB}[6,35,38]$ and in Bifidobacteria [39]. Only one report, however addressed behavior of L. acidophilus in an oxidative 
environment [40] showing increased NADH oxidase and NADH peroxidase together with $\mathrm{H}_{2} \mathrm{O}_{2}$ decomposing ability upon exposure to $21 \%$ oxygen.

In the present study $1.2 \mathrm{mM} \mathrm{H}_{2} \mathrm{O}_{2}$ was not lethal L. acidophilus NCFM but prolonged lag phase latency which together with a shallower exponential growth compared to control cultures, underlined that time is needed to recover from oxidative damage. Lower $\mathrm{H}_{2} \mathrm{O}_{2}(>0.4 \mathrm{mM})$ was harmful to L. acidophilus NCFM in the BioScreen experiment, probably reflecting increased exposure to oxygen due to small wells and larger surface in the culture plates which augmented $\mathrm{H}_{2} \mathrm{O}_{2}$ sensitivity.

Remarkably, several identified enzymes with increased abundance in $1.2 \mathrm{mM} \mathrm{H}_{2} \mathrm{O}_{2}$-treated $L$.

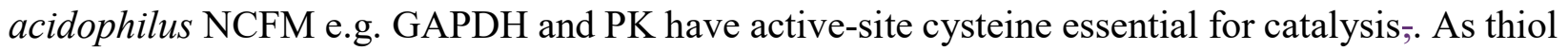
groups are very sensitive to oxidative stress [22], we speculate de novo synthesis of these enzymes and cysteine synthase is triggered to overcome oxidative damage. Moreover, as 2DE allows monitoring multiple protein forms, oxidative stress could be observed to cause increased and reduced abundance for different protein species derived from the same gene, as described below.

\subsection{Energy metabolism}

GAPDH of $42 \mathrm{kDa}$ (spots 10 and 12,) increased $>+1.3$-fold in relative abundance, while GAPDH of $27 \mathrm{kDa}$ (spot 27) significantly decreased $(-1.75 ; \mathrm{p}<0.01)$. Notably RT-PCR of the GAPD gene (lba0698, Supporting Fig. S2) showed essentially no overall change under oxidative stress compared to control, whereas the 2DE analysis revealed specific GAPDH forms to be either increased or decreased in abundancy. Previously, proteomics showed two isozymes in Lactobacillus spp., GAPDH II (41 kDa), and GAPDH I (38 kDa) exhibiting different expression profiles, but only synthesis of GAPDH II was repressed by amino acids in the culture medium 
[41]. The three L. acidophilus NCFM GAPDH forms are encoded by a single gene (Table 1) supporting stress affects post-translational modifications (PTMs). GAPDH is an evolutionary wellconserved moonlighting protein playing various cellular roles [42, 43]. Jungblut et al. [44] and Schluter et al. [45] discussed several GAPDH PTM forms and hypothesized that they exert different physiological functions. In Eukarya, for example GAPDH nitrosylated by environmental $\mathrm{NO}$ is involved in control of apoptosis and not in energy metabolism [45]. Additionally, GAPDH acts as a redox sensor, and after appropriate PTM, as mediator of DNA repair in response to oxidative stress [46]. The increased relative abundance in $\mathrm{H}_{2} \mathrm{O}_{2}$ of both $42 \mathrm{kDa}$ GAPDH and DNA repairing enzymes (see below) in L. acidophilus NCFM supports that this GAPDH species in bacteria may be a redox sensor eliciting DNA repair mechanisms. GAPDH was also target of oxidative modifications in microorganisms due to the active site cysteine [47]. Thus, higher copy number of GAPDH could secure functions during oxidative stress. Increased abundance of GAPDH under different stresses, such as high selenium exposure, has been demonstrated in other LAB [48].

Two protein species of $\mathrm{PK}$ in $\mathrm{H}_{2} \mathrm{O}_{2}$ occur with increased abundance: spot 72 changing +1.42 fold, and spot 32 change +1.32 -fold, although the analysis of the latter was less reliable (Table 1 ). They are products of the same gene. Different molecular mass (68.25 and 68.75) and pI (5.41 and 5.31) values support they differ in PTM (Fig. 3; Table 1). PK is the last enzyme of the Embden-Meyerhof pathway and plays a central role in the metabolism of microaerophilic LAB. It catalyzes formation of pyruvate and produces ATP by phosphate transfer from phosphoenolpyruvate to ADP. Higher amounts of PK, as in the present study, leads to more ATP by substrate level phosphorylation, improving handling of enhanced energy requirement linked to stress. PK has three functional cysteines susceptible to oxidization, $\mathrm{Cys}^{358}$ essential for catalysis, and Cys ${ }^{31}$ and $\mathrm{Cys}^{424}$ involved 
in subunit interface interaction [49]. Overexpression of PK can compensate for various inactivating reactions and elevated pyruvate production in Pseudomonas fluorescens was part of adaptation to $\mathrm{H}_{2} \mathrm{O}_{2}$ stress [50]. Moreover, the abundance change of PK was confirmed by slight increase in $\underline{\text { lba0957 gene expression observed by RT-PCR (Supporting Fig. S2). }}$

\subsection{Nucleic acids}

Ribonucleoside triphosphate reductase ( ppot $3 ;+1.3$ fold) was identified with high MASCOT score and $36 \%$ sequence coverage. It catalyzes reduction of ribonucleotides to deoxyribonucleotides providing all dNTPs for DNA synthesis and repair and is a target of concerted modulations at molecular and cellular levels [51]. Ribonucleoside triphosphate reductase is coupled with a thioredoxin supplying reducing power for its reaction $[52,53]$, and the increase in abundance generates building blocks to repair damaged DNA. In E. coli, abundance increased of only one of two ribonucleoside triphosphate reductase isoforms increased in abundance during oxidative stress, especially in strains lacking other antioxidant systems [54]. Similarly, in the present investigation one spot (spot 3$)$ increased with good significance $(p<0.05)$, suggesting an analogous regulation in L. acidophilus NCFM.

Ribose-p pyrophosphokinase (PRPPS) is present in two forms (spots 13 and 18) derived from different genes (LBA0131 and LBA0224, respectively). According to KEGG they are isozymes having the same specificity (EC 2.7.6.1). They differ significantly both in their molecular mass (40.25 and 35.75) and in pI (6.67 and 6.97). One of them (spot 18) showed increased abundance (+1.37-fold) during oxidative stress caused by $\mathrm{H}_{2} \mathrm{O}_{2}$. Ribose-p pyrophosphokinase catalyzes transfer of diphosphate from ATP to ribose-5-phosphate (R5P) generating 5-phospho- $\alpha$-d-ribosyl1-pyrophosphate (PRPP) involved in nucleotide biosynthesis. PRPPS also has a role in 
biosynthesis of histidine, tryptophan and pyridine nucleotide coenzymes [55] of which especially NADH is involved in regeneration of antioxidant enzymes. In rats, oxidative modifications of PRPPS affect enzyme activity and hence PRPP availability [57]. L. acidophilus NCFM needs PRPP for repair of ROS-damaged nucleic acids and de novo synthesis of DNA.

\subsection{General stress proteins}

L. acidophilus NCFM heat shock protein GrpE (spot 28) related to DnaK [57, 58] possessing chaperone functions decreased in abundance $(-1.30)$ by $\mathrm{H}_{2} \mathrm{O}_{2}$ exposure, and expression of its gene (lba1248) was decreased dramatically ( -35 fold; Supporting Fig. S2). In all living organisms, cellular stress responses are concerted to avoid harmful conditions, adjust reversible modifications and eliminate irreversibly destroyed molecules. To fulfill these purposes, different stress proteins are synthesized as classified according to their main function: i) modifying/protecting enzymes (e.g. regulating lipid/protein ratio or unsaturated/saturated lipids ratio in membranes, during stress), ii) refolding proteins (chaperones) or iii) hydrolytic enzymes (proteases including chaperone-proteases degrading destroyed cellular structures). Generally, when damage is light, refolding chaperons are able to restore functional proteins, whereas under harsher conditions degradation by proteolytic enzymes prevails. The present results indicate that part of the chaperone function is limited by oxidative stress in L. acidophilus NCFM, whereas the ClpP-ATP-dependent protease-peptidase subunit (spot 21) increased +1.38 fold (good MASCOT score; Table 1). This suggests $\mathrm{H}_{2} \mathrm{O}_{2}$ caused irreversible protein damage and that $\mathrm{ClpP}$ hydrolyzes unfolded or misfolded proteins and recycle amino acids for de novo protein synthesis.

\subsection{Oxidative stress-related proteins}


Cysteine synthase increased during oxidative stress ( spot $34 ;+1.32$ fold; $p=0.09$ ) amplifies the cysteine pool and hence availability of cysteine-containing enzymes (e.g. GAPDH and PK) as well as disulfide bonds important for protein stability. This finding agrees with cysteine synthase reported to protect Staphylococcus aureus against $\mathrm{H}_{2} \mathrm{O}_{2}$-induced stress [60]. Secondly, cysteines are at the similar active sites in thioredoxin and glutaredoxin, the most universally used antioxidant systems in living organisms [25, 32, 59], and undergo intramolecular disulfide bond formation in the presence of oxidizing agents. L. acidophilus NCFM contains these two members of the disulfide-reducing pathway. Increased abundance of cysteine synthase may be a first step to boost the disulfide-reducing pathway.

Antibiotic biosynthesis monooxygenase (ABM) (spot 52) showing -1.61 fold abundance change $(\mathrm{p}<0.05)$ and dramatic decrease in gene expression (lba0497, -4.5 fold; Supporting Fig. S2) is a non-heme monooxygenase having a ferredoxin-like fold and catalyzing oxidation by activation of molecular oxygen to the hydroxyl-radical reacting with substrate [61]. In many monooxygenases, e.g. phenol-hydroxylase, uncoupling in the catalytic cycle forms ROS [60] and decreased ABM in $\mathrm{H}_{2} \mathrm{O}_{2}$-treated L. acidophilus NCFM reduce the overall accumulation of free radicals in the environment already rich in ROS.

\section{Concluding remarks}

Molecular aspects connected with growth of L. acidophilus NCFM in an oxidizing environment were disclosed using 2DE-based comparative proteomics. The main metabolic responses to $\mathrm{H}_{2} \mathrm{O}_{2}$ stress consisted in enhancement of energy metabolism and nucleic acid repair. With regard to general stress responses, proteolytic degradation seems prevalent over refolding (chaperones), probably because $\mathrm{H}_{2} \mathrm{O}_{2}$ severely damages proteins. Furthermore, specific oxidative-stress related 
enzymes were detected, among which cysteine synthase deserves attention due to the role of cysteine residues in protein stability, catalytic sites, and disulfide-reducing pathways in overcoming oxygen stress.

The findings provide new insights into mechanisms of L. acidophilus NCFM oxidative stress resistance, anticipated to favor survival in industrial processes. Knowing how levels of proteins and metabolic pathways are regulated during oxidative stress are helpful for i) screening for tolerant strains by gene bio-typing, ii) understanding whether cells are fully adapted and able to survive or, conversely, are stressed and will be suboptimal in the process, and iii) optimizing growth conditions and media to improve fitness during culture. Finally, as suggested [22], identification of crucial stress-related proteins can reveal candidates for manipulation at the gene level to gain stress resistance.

The present global identification of $\mathrm{H}_{2} \mathrm{O}_{2}$-induced protein abundance changes in L. acidophilus NCFM sheds new light on LAB response to oxidative stress. This represents a starting point for future investigations and integration of transcriptome and metabolome analyses. From a practical stand-point, acclimatization procedures can trigger induction of adaptive responses that can increase bacterial tolerance to stress which per se can be useful to improve strains for harsh industrial conditions. 


\section{Acknowledgements}

Karina Jansen and Anne Blicher are thanked for technical assistance and Regina Åris Schürmann for use of the BioScreen instrument. The Center for Advanced Food Studies (LMC) contributed to the acquisition of the mass spectrometer. This work was supported by the Danish Strategic Research Council's Program Committee on Health, Food and Welfare. Elia Calderini and Julia Villarroel benefitted from an Erasmus agreement to perform their master projects at DTU. Hasan Ufuk Celebioglu is grateful to the Republic of Turkey, Ministry of National Education for a PhD scholarship.

\section{Conflict of interest}

The authors declare no conflict of interest. 


\section{References}

[1] Carr, F. J., Chill, D., Maida, N., The lactic acid bacteria: A literature survey. Crit. Rev. Microbiol. 2002, 28, 281-370.

[2] Pessione, A., Lamberti, C., Pessione, E., Proteomics as a tool for studying energy metabolism in lactic acid bacteria. Mol. Biosyst. 2010, 6, 1419-1430.

[3] Whittenbury, R., Hydrogen peroxide formation and catalase activity in the lactic acid bacteria. J. Gen. Microbiol. 1964, 35, 13-26.

[4] Mares, A., Neyts, K., Debevere, J., Influence of $\mathrm{pH}$, salt and nitrite on the heme-dependent catalase activity of lactic acid bacteria. Intl. J. Food Microbiol. 1994, 24, 191-198.

[5] Pessione, E., Lactic acid bacteria contribution to gut complexity: lights and shadows. Front. Cell. Infect. Microbiol. 2012, 2-86.

[6] Guerzoni, M. E., Lanciotti, R., Cocconcelli, P. S., Alteration in cellular fatty acid composition as a response to salt, acid, oxidative and thermal stresses in Lactobacillus helveticus. Microbiology 2001, 147, 2255-2264.

[7] Jobin, M. P., Garmyn, D., Diviès, C., Guzzo, J., Expression of the Oenococcus oeni trxA gene is induced by hydrogen peroxide and heat shock. Microbiology 1999, 145, 1245-1251.

[8] Toledano, M. B., Kumar, C., Le Moan, N., Spector, D., Tacnet, F., The system biology of thiol redox system in Escherichia coli and yeast: Differential functions in oxidative stress, iron metabolism and DNA synthesis. FEBS Lett. 2007, 581, 3598-3607.

[9] Scott, C., Rawsthorne, H., Upadhyay, M., Shearman, C. A. et al., Zn uptake, oxidative stress and the FNR-like proteins in Lactococcus lactis. FEMS Microbiol. Lett. 2000, 192, 85-89. 
[10] Miyoshi, A., Rochat, T., Gratadoux, J. J., Le Loir, Y. et al., Oxidative stress in Lactococcus lactis. Genet. Mol. Res. 2003, 2, 348-359.

[11] van de Guchte, M., Serror, P., Chervaux, C., Smokvina, T. et al., Stress responses in lactic acid bacteria. Antonie Van Leeuwenhoek 2002, 82, 187-216.

[12] Pessione, E., Probiotic social life, biochemical cross-talk and ecological relationships among bacteria. In E. Pessione (Ed.), Interactive Probiotics. CRC Press, Boca Raton 2014, pp 1-21.

[13] Siroli, L., Patrignani, F., Serrazanetti, D. I., Tabanelli, G. et al., Lactic acid bacteria and natural antimicrobials to improve the safety and shelf-life of minimally processed sliced apples and lamb's lettuce. Food Microbiol. 2015, 47, 74-84.

[14] Kailasapathy, K., Chin, J., Survival and therapeutic potential of probiotic organisms with reference to Lactobacillus acidophilus and Bifidobacterium spp. Immunol. Cell Biol. 2000, $78,80-88$.

[15] Ouwehand, A. C., Bianchi Salvadori, B., Fondén, R., Mogensen, G. et al., Health effects of probiotics and culture-containing dairy products in humans. Bull. Intl. Dairy Fed. 2003, 380, 4-19.

[16] Tompkins, T. A., Hagen, K. E., Wallace, T. D., Fillion-Forte, V., Safety evaluation of two bacterial strains used in Asian probiotic products. Can. J. Microbiol. 2008, 54, 391-400.

[17] Thirabunyanon, M., Hongwittayakorn, P., Potential probiotic lactic acid bacteria of human origin induce antiproliferation of colon cancer cells via synergic actions in adhesion to cancer cells and short-chain fatty acid bioproduction. Appl. Biochem. Biotechnol. 2013, 169, $511-525$. 
[18] de Almeida Junior, W. L. G., da Silva Ferrari, I., de Souza, J. V., Barbosa, A. L. et al., Principal criteria for selection of lactic acid bacteria for potential use as probiotics in foods. Afr. J. Microbiol. Res. 2015, 9, 671-686.

[19] Klaenhammer, T. R., Functional activities of Lactobacillus probiotics: Genetic mandate. Int. Dairy J. 1998, 8, 497-505.

[20] Lebeer, S., Vanderleyden, J., De Keersmaecker, S. C., Genes and molecules of lactobacilli supporting probiotic action. Microbiol. Mol. Biol. Rev. 2008, 72, 728-764.

[21] Sanders, M. E., Klaenhammer, T. R., The scientific basis of Lactobacillus acidophilus NCFM functionality as a probiotic. J. Dairy Sci. 2001, 84, 319-331.

[22] Mills, S., Stanton, C., Fitzgerald, G. F., Ross, R. P., Enhancing the stress responses of probiotics for a lifestyle from gut to product and back again. Microb. Cell Fact. 2011, 10 (Suppl 1), S19.

[23] Weinbreck, F., Bodnár, I., Marco, M. L., Can encapsulation lengthen the shelf-life of probiotic bacteria in dry products? Int. J. Food Microbiol. 2010, 136, 364-367.

[24] Bolduc, M. P., Raymond, Y., Fustier, P., Champagne, C. P., Vuillemard, J. C., Sensitivity of bifidobacteria to oxygen and redox potential in non-fermented pasteurized milk. Int. Dairy J. 2006, 16, 1038-1048.

[25] Altermann, E., Russell, W. M., Azcarate-Peril, M. A., Barrangou, R., et al., Complete genome sequence of the probiotic lactic acid bacterium Lactobacillus acidophilus NCFM. Proc. Natl. Acad. Sci. U. S. A. 2005, 102, 3906-3912.

[26] Barrangou, R., Altermann, E., Hutkins, R., Cano, R., Klaenhammer, T. R., Functional and comparative genomic analyses of an operon involved in fructooligosaccharide utilization by Lactobacillus acidophilus. Proc. Natl. Acad. Sci. U.S.A. 2003, 100, 8957-8962. 
[27] Bruno-Bárcena, J. M., Andrus, J. M., Libby, S. L., Klaenhammer, T. R., Hassan, H. M., Expression of a heterologous manganese superoxide dismutase gene in intestinal lactobacilli provides protection against hydrogen peroxide toxicity. Appl. Environ. Microbiol. 2004, 70, 4702-4710.

[28] Oberg, T. S., Steele, J. L., Ingham, S. C., Smeianov, V. V. et al., Intrinsic and inducible resistance to hydrogen peroxide in Bifidobacterium species. J. Ind. Microbiol. Biotechnol. 2011, 38, 1947-1953.

[29] Majumder, A., Sultan, A., Jersie-Christensen, R. R., Ejby, M. et al., Proteome reference map of Lactobacillus acidophilus NCFM and quantitative proteomics towards understanding the prebiotic action of lactitol. Proteomics 2011, 11, 3470-3481.

[30] Jiang, Y., Yang, B., Harris, N. S., Deyholos, M. K., Comparative proteomic analysis of NaCl stress-responsive proteins in Arabidopsis roots. J. Exptl. Bot. 2007, 58, 3591-3607.

[31] Candiano, G., Bruschi, M., Musante, L., Santucci, L. et al., Blue silver: a very sensitive colloidal Coomassie G-250 staining for proteome analysis. Electrophoresis 2004, 25, $1327-$ 1333.

[32] Serata, M., Iino, T., Yasuda, E., Sako, T., Roles of thioredoxin and thioredoxin reductase in the resistance to oxidative stress in Lactobacillus casei. Microbiology 2012, 158, 953-962.

[33] Rolfe, M. D., Rice, C. J., Lucchini, S., Pin, C., Thompson, A. et al., Lag phase is a distinct growth phase that prepares bacteria for exponential growth and involves transient metal accumulation. J. Bacteriol. 2012, 194, 686-701.

[34] Beltramo, C., Grandvalet, C., Pierre, F., Guzzo, J., Evidence for multiple levels of regulation of Oenococcus oeni clpP-clpL locus expression in response to stress. J. Bacteriol. 2004, 186, 2200-2205. 
[35] De Angelis, M., Gobbetti, M., Environmental stress responses in Lactobacillus: a review. Proteomics 2004, 4, 106-122.

[36] Xiao, M., Xu, P., Zhao, J., Wang, Z., Zuo et al., Oxidative stress-related responses of Bifidobacterium longum subsp. longum BBMN68 at the proteomic level after exposure to oxygen. Microbiology 2011, 157, 1573-1588

[37] Guilbaud, M., Zagorec, M., Chaillou, S., Champomier-Verges, M. C., Intraspecies diversity of Lactobacillus sakei response to oxidative stress and variability in mixed strains challenges. Food Microbiol. 2012, 29, 197-204.

[38] Parente, E., Ciocia, F., Ricciardi, A., Zotta, T., et al., Diversity of stress tolerance in Lactobacillus plantarum, Lactobacillus pentosus and Lactobacillus paraplantarum: a multivariate screening study. Int. J. Food Microbiol. 2010, 144, 270-279.

[39] Ruiz L., Ruas-Madiedo P.,Gueimonde M., Delos Reyes-Gavilan C.G.,Margolles A. et al., How do Bifidobacteria counteract environmental challenges? Mechanisms involved and physiological consequences. Genes Nutr. 2011, 6, 307-318.

[40] Talwalkar, A., Kailasapathy, K., Metabolic and biochemical responses of probiotic bacteria to oxygen. J. Dairy Sci. 2003, 86, 2537-2546.

[41] Pessione, E., Mazzoli, R., Giuffrida, M. G., Lamberti, C. et al., A proteomic approach to studying biogenic amine producing lactic acid bacteria. Proteomics 2005, 5, 687-698.

[42] Jeffery, C. J., Moonlighting proteins. Trends Biochem. Sci. 1999, 24, 8-11.

[43] Jeffery C. J., Molecular mechanisms for multitasking: Recent crystal structures of moonlighting proteins. Curr. Opin. Struct. Biol. 2004, 14, 663-668.

[44] Jungblut, P. R., Holzhutter, H. G., Apweiler, R., Schluter, H., The speciation of the proteome. Chem. Cent. J. 2008, 2, article 16. 
[45] Schluter, H., Apweiler, R., Holzhutter, H. G., Jungblut, P. R., Finding one's way in proteomics: a protein species nomenclature. Chem. Cent. J. 2009, 3, article 11.

[46] Tristan, C., Shahani, N., Sedlak, T. W., Sawa, A., The diverse functions of GAPDH: views from different subcellular compartments. Cell. Signalling 2011, 23, 317-323.

[47] Grant, C. M., Quinn, K. A., Dawes, I. W., Differential protein S-thiolation of glyceraldehyde3-phosphate dehydrogenase isoenzymes influences sensitivity to oxidative stress. Mol. Cell. Biol. 1999, 19, 2650-2656.

[48] Lamberti, C., Mangiapane, E., Pessione, A., Mazzoli, R. et al., Proteomic characterization of a selenium-metabolizing probiotic Lactobacillus reuteri $\mathrm{Lb} 2 \mathrm{BM}$ for nutraceutical applications. Proteomics 2011, 11, 2212-2221.

[49] Anastasiou, D., Poulogiannis, G., Asara, J. M., Boxer, M. B. et al., Inhibition of pyruvate kinase M2 by reactive oxygen species contributes to cellular antioxidant responses. Science $2011,334,1278-1283$.

[50] Bignucolo, A., Appanna, V. P., Thomas, S. C., Auger, C. et al., Hydrogen peroxide stress provokes a metabolic reprogramming in Pseudomonas fluorescens: Enhanced production of pyruvate. J. Biotechnol. 2013, 167, 309-315.

[51] Nordlund, P., Reichard, P., Ribonucleotide reductases. Annu. Rev. Biochem. 2006, 75, 681-706.

[52] Orr, M. D., Vitols, E., Thioredoxin from Lactobacillus leichmannii and its role as hydrogen donor for ribonucleoside triphosphate reductase. Biochem. Biophys. Res. Commun. 1966, 25, 109-115.

[53] Zeller, T., Klug, G., Thioredoxins in bacteria: functions in oxidative stress response and regulation of thioredoxin genes. Naturwissenschaften 2006, 93, 259-266. 
[54] Monje-Casas, F., Jurado, J., Prieto-Álamo, M. J., Holmgren, A., Pueyo, C., Expression analysis of the nrdHIEF operon from Escherichia coli. Conditions that trigger the transcript level in vivo. J. Biol. Chem. 2001, 276, 18031-18037.

[55] Eriksen, T. A., Kadziola, A., Bentsen, A. K., Harlow, K. W., Larsen, S., Structural basis for the function of Bacillus subtilis phosphoribosyl-pyrophosphate synthetase. Nat. Struct. Mol. Biol. 2000, 7, 303-308.

[56] Poon, H. F., Calabrese, V., Calvani, M., Butterfield, D. A., Proteomics analyses of specific protein oxidation and protein expression in aged rat brain and its modulation by Lacetylcarnitine: insights into the mechanisms of action of this proposed therapeutic agent for CNS disorders associated with oxidative stress. Antioxid. Redox Sign. 2006, 8, 381-394.

[57] Harrison, C., GrpE, a nucleotide exchange factor for DnaK. Cell. Stress Chaperon. 2003, 8, $218-224$.

[58] Gelinas, A. D., Toth, J., Bethoney, K. A., Langsetmo, K. et al., Thermodynamic linkage in the GrpE nucleotide exchange factor, a molecular thermosensor. Biochemistry 2003, 42, 9050-9059.

[59] Vido, K., Diemer, H., Van Dorsselaer, A., Leize, E. et al., Roles of thioredoxin reductase during the aerobic life of Lactococcus lactis. J. Bacteriol. 2005, 187, 601-610.

[60] Lithgow, J. K., Hayhurst, E. J., Cohen, G., Aharonowitz, Y., Foster, S. J., Role of a cysteine synthase in Staphylococcus aureus. J. Bacteriol. 2004, 186, 1579-1590.

[61] Divari, S., Valetti, F., Caposio, P., Pessione, E. et al., The oxygenase component of phenol hydroxylase from Acinetobacter radioresistens S13. Eur. J. Biochem. 2003, 270, 2244-2253. 


\section{Captions to figures}

Figure 1. BioScreen of Lactobacillus acidophilus NCFM (see Methods). Growth under stress: 0.2 $(\square), 0.4(-\triangle), 0.6(-x), 0.8(*), 1(-)), 1.2(+)) \mathrm{mM} \mathrm{H}_{2} \mathrm{O}_{2}$ and control $\left(0 \mathrm{M} \mathrm{H}_{2} \mathrm{O}_{2},-\diamond\right)$ are displayed.

Figure 2. Growth (solid lines) and pH (broken lines) curves of Lactobacillus acidophilus NCFM under control ( $\diamond$ and -- --$)$ and stress conditions: 0.8 ( $\square$ and --*--) and $1.2(\triangle$ and -- $\bullet--)$ mM $\mathrm{H}_{2} \mathrm{O}_{2}$ (A) and of a representative colony of L. acidophilus NCFM after a sub-culturing step (B). The arrows show the harvest time of cells for proteome analysis.

Figure 3. Comparison of 2DE spot patterns of intracellular soluble proteomes. A. Representative 2DE images of intracellular soluble proteins of L. acidophilus NCFM treated with $1.2 \mathrm{mM} \mathrm{H}_{2} \mathrm{O}_{2}$. B. Selected spots illustrating differential relative abundance when treated with oxidative stress. Mean values of fold changes are indicated. 


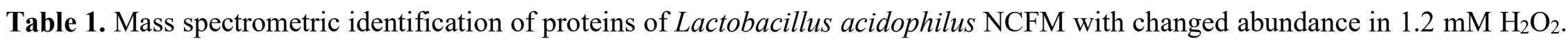
pI and MW are obtained by using the algorithm in SameSpots (TotalLab). Fold changes with standard deviations (S.D) are mean values from four biological replicates.

\begin{tabular}{|c|c|c|c|c|c|c|c|c|c|}
\hline $\begin{array}{c}\text { Spot } \\
\text { No }^{\circ}\end{array}$ & $\begin{array}{c}\text { Fold } \\
\text { Change } \pm \text { S.D. }\end{array}$ & $\begin{array}{c}\mathbf{p} \\
\text { value }\end{array}$ & Accession & Protein name & $\begin{array}{c}\text { MW/pI } \\
\text { theoretical }\end{array}$ & $\begin{array}{c}\mathrm{MW} / \mathrm{pI} \\
\text { measured }\end{array}$ & $\begin{array}{l}\text { PMF } \\
\text { score }\end{array}$ & E-value & $\begin{array}{c}\text { Sequence } \\
\text { coverage \% }\end{array}$ \\
\hline 2 & $+1.34 \pm 0.64$ & 0.3 & YP_193550 & p-enolpyruvate-protein $\mathrm{p}$-transferase PTSI & $63.89 / 4.79$ & $83.5 / 5.08$ & 160 & $2.50 \mathrm{E}-09$ & $44 \%$ \\
\hline 3 & $+1.30 \pm 0.14$ & 0.02 & YP_192977 & ribonucleoside triphosphate reductase & $83.98 / 5.62$ & $87.5 / 6.08$ & 220 & $2.5 \mathrm{E}-15$ & $36 \%$ \\
\hline 10 & $+1.45 \pm 0.25$ & 0.09 & YP_193604 & glyceraldehyde-3-p dehydrogenase & $36.64 / 5.92$ & $43 / 5.98$ & 195 & $7.80 \mathrm{E}-13$ & $52 \%$ \\
\hline 11 & $+1.55 \pm 0.55$ & 0.1 & YP_193604 & glyceraldehyde-3-p dehydrogenase & $36.64 / 5.92$ & $43.25 / 6.15$ & 227 & $4.90 \mathrm{E}-16$ & $61 \%$ \\
\hline 12 & $+1.30 \pm 0.20$ & 0.05 & YP_193604 & glyceraldehyde-3-p dehydrogenase & $36.64 / 5.92$ & $42 / 6.51$ & 232 & $1.6 \mathrm{E}-16$ & $67 \%$ \\
\hline 13 & $+1.34 \pm 0.59$ & 0.3 & YP_193063 & ribose-p pyrokinase & $36.71 / 5.81$ & $40.25 / 6.67$ & 125 & $7.8 \mathrm{E}-06$ & $29 \%$ \\
\hline 14 & $+1.42 \pm 0.72$ & 0.3 & YP_193604 & glyceraldehyde-3-p dehydrogenase & $36.64 / 5.92$ & $42.25 / 6.72$ & 206 & $6.2 \mathrm{E}-14$ & $58 \%$ \\
\hline 18 & $+1.37 \pm 0.30$ & 0.09 & YP_193150 & ribose-p-pyrophosphokinase & $35.68 / 6.01$ & $35.75 / 6.97$ & 77 & 0.26 & $28 \%$ \\
\hline 21 & $+1.38 \pm 0.35$ & 0.1 & WP_003547145 & ATP-dependent protease peptidase subunit & $18.76 / 5.21$ & $22 / 5.79$ & 102 & 0.0016 & $44 \%$ \\
\hline 26 & $-1.43 \pm 0.31$ & 0.1 & YP_194367 & transcriptional elongation factor & $17.31 / 4.54$ & $28.75 / 4.38$ & 93 & 0.013 & $58 \%$ \\
\hline
\end{tabular}




\begin{tabular}{|c|c|c|c|c|c|c|c|c|c|}
\hline 27 & $-1.75 \pm 0.12$ & 0.01 & YP_193604 & glyceraldehyde-3-p dehydrogenase & $36.64 / 5.92$ & $27.25 / 5.89$ & 186 & $6.2 \mathrm{E}-12$ & $45 \%$ \\
\hline 28 & $-1.30 \pm 0.04$ & 0.09 & YP_194112 & heat shock protein GrpE & $22.04 / 5.79$ & $27 / 6.29$ & 94 & 0.0099 & $41 \%$ \\
\hline 32 & $+1.32 \pm 0.36$ & 0.17 & YP_193840 & pyruvate kinase & $63.14 / 5.23$ & $68.25 / 5.41$ & 222 & $1.2 \mathrm{E}-15$ & $38 \%$ \\
\hline 34 & $+1.32 \pm 0.26$ & 0.09 & YP_194102 & cysteine synthase & $32.66 / 6.99$ & $35 / 8.19$ & 164 & $9.8 \mathrm{E}-10$ & $62 \%$ \\
\hline \multirow[t]{2}{*}{35} & $+1.31 \pm 0.37$ & 0.19 & YP_194428 & phenylalanyl-tRNA synthetase subunit beta & $23.73 / 4.75$ & $33.75 / 4.92$ & 132 & $1.6 \mathrm{E}-06$ & $72 \%$ \\
\hline & & & YP_194361 & $\mathrm{N}$-acetylglucosamine kinase & $32.9 / 4.76$ & & 101 & 0.002 & $42 \%$ \\
\hline 39 & $+1.56 \pm 0.9$ & 0.3 & YP_193706 & cell division protein FtsZ & $48.12 / 4.55$ & $66.5 / 4.34$ & 140 & $2.50 \mathrm{E}-07$ & $48 \%$ \\
\hline \multirow[t]{2}{*}{52} & $-1.61 \pm 0.22$ & 0.04 & WP_011254170 & antibiotic biosynthesis monooxygenase & $24.69 / 4.85$ & $36.25 / 4.99$ & 141 & $2 \mathrm{E}-07$ & $46 \%$ \\
\hline & & & & & & & 91 & & $30 \%$ \\
\hline 64 & $-1.47 \pm 0.17$ & 0.2 & YP_194106 & adenine phosphoribosyltransferase & $19.34 / 6.1$ & $30 / 6.72$ & 147 & $4.9 \mathrm{E}-08$ & $60 \%$ \\
\hline 72 & $1.42 \pm 0.31$ & 0.07 & YP_193840 & pyruvate kinase & $63.14 / 5.23$ & $68.75 / 5.31$ & 217 & $4.9 \mathrm{E}-15$ & $38 \%$ \\
\hline
\end{tabular}

